DEMOGRAPHIC RESEARCH

VOLUME 41, ARTICLE 10, PAGES 263-292

PUBLISHED 24 JULY 2019

https://www.demographic-research.org/Volumes/Vol41/10/

DOI: 10.4054/DemRes.2019.41.10

Research Article

Earning their keep? Fostering, children's education, and work in north-western Tanzania

Sophie Hedges

Rebecca Sear

Jim Todd

Mark Urassa

David Lawson

(C) 2019 Hedges, Sear, Todd, Urassa \& Lawson.

This open-access work is published under the terms of the Creative Commons Attribution 3.0 Germany (CC BY 3.0 DE), which permits use, reproduction, and distribution in any medium, provided the original author(s) and source are given credit.

See https://creativecommons.org/licenses/by/3.0/de/legalcode. 


\section{Contents}

$1 \quad$ Background 264

$1.1 \quad$ Why care for foster children? 265

$\begin{array}{lll}1.2 & \text { Study context and predictions } & 267\end{array}$

2 Methods 268

2.1 Data collection 268

$\begin{array}{lll}2.2 & \text { Data analysis } & 269\end{array}$

3 Results 271

$\begin{array}{lll}3.1 & \text { Descriptive results } & 271\end{array}$

3.1.1 Comparison of households with and without foster children 271

3.1.2 Child characteristics $\quad 272$

$\begin{array}{lll}3.2 & \text { Educational outcomes } & 273\end{array}$

$\begin{array}{lll}3.3 & \text { Farm and paid work during past week } & 276\end{array}$

$\begin{array}{lll}3.4 & \text { Trade-off between work and education } & 278\end{array}$

4 Discussion $\quad 281$

4.1 Limitations 284

$\begin{array}{lll}4.2 & \text { Conclusions } & 284\end{array}$

5 Acknowledgements 285

References 286 


\title{
Earning their keep? Fostering, children's education, and work in north-western Tanzania
}

\author{
Sophie Hedges ${ }^{1}$ \\ Rebecca Sear ${ }^{2}$ \\ Jim Todd ${ }^{2}$ \\ Mark Urassa ${ }^{3}$ \\ David Lawson ${ }^{4}$
}

\begin{abstract}
BACKGROUND

Fostering, raising children that are not one's biological children, is common in many societies worldwide. Despite predicted lower investment in nonbiological offspring, numerous studies report no obvious well-being penalty for fostered children. Building on prior research, we suggest that fostering is incentivised by close relatedness between foster child and caregivers and that children's work contributions can offset their costs to fostering households.
\end{abstract}

\section{METHOD}

We used multilevel logistic and fractional multinomial regression analyses to investigate the association between fostering, educational investment, and time allocation in a sample of 1,273 Sukuma children (aged 7-19) from northwestern Tanzania, where fostering is traditionally common.

\section{RESULTS}

Twenty-six per cent of children are fostered, with most having at least one living parent. Children fostered by close kin have similar educational outcomes to those living with both biological parents, though their grade for age is lower, perhaps reflecting differences in timing rather than overall level of investment. Those fostered by distant kin are less likely to be enrolled or to progress to secondary school. Overall, fostered children are more likely to do farm work; however on weekdays when work conflicts

\footnotetext{
${ }^{1}$ London School of Hygiene and Tropical Medicine, London, UK. Email: sophie.hedges@1shtm.ac.uk.

${ }^{2}$ London School of Hygiene and Tropical Medicine, London, UK.

${ }^{3}$ National Institute for Medical Research, London, UK.

${ }^{4}$ University of California, Santa Barbara, USA.
} 
with school, differences in time allocation to work activities are not pronounced. We further find that orphans are generally not particularly disadvantaged compared to other fostered children.

\section{CONCLUSION}

Being fostered by close kin does not appear to disadvantage children, and buffers orphans from parental death. Fostered children may offset some of their costs through increased farm work.

\section{CONTRIBUTION}

We extend previous work in this area through analysis of detailed time allocation data, providing insights into associations between fostering and children's workload.

\section{Background}

Fostering, i.e., permanently or temporarily raising children that are not one's biological children, is common in many societies worldwide (Silk 1980; Scelza and Silk 2014). Across 40 countries in sub-Saharan Africa, $8.6 \%$ of children aged 15 and under were estimated to be fostered in 2002, with the frequency of fostering amplified in regions where HIV has increased the incidence of orphanhood (Monasch and Boerma 2004: S58). In societies with strong traditions of fostering, fostering can begin at young ages, and frequently occurs even when both parents are alive. Lawson et al. (2017), for example, report that in northern Tanzania, $6 \%$ of children under five years of age resided apart from both living parents, most often with grandparents. Another study at a site in rural eastern Tanzania estimates that $25 \%$ of children experienced maternal absence, and $40 \%$ paternal absence, by age 10 (Gaydosh 2015). The widespread practice of fostering seemingly contradicts the otherwise well-supported assumption that parental care is incentivised by close genetic relatedness between caretaker and child (Hamilton 1964; Silk 1980). In this paper we consider the possibility that, in addition to foster parents usually being close kin, foster children offset the costs of their care through contributions to household labour (Reghupathy et al. 2012). In doing so we present novel data on children's time allocation in a rural Sukuma population from north-western Tanzania. We begin by first reviewing past research on parental motivations for out-fostering children and the well-being implications for fostered children, before considering the incentives for foster parents. We then introduce our study context and predictions.

Anthropological accounts of fostering have highlighted the potential benefits parents may derive from out-fostering children, even if it disadvantages children. 
Potential benefits include forging advantageous alliances with other households, alleviating resource scarcity if they cannot support all their children, or adjusting the sex ratio of their household (Goody 1982; Franklin and Volk 2016). The overall benefits to parents of out-fostering may therefore outweigh any potential negative impacts on the well-being of an individual child. Among the Mende in Sierra Leone, Bledsoe (1990) reported that foster children receive harsh treatment, but that parents value the status gains made by fostering children out to wealthier households. Among the Himba in Namibia, Scelza and Silk (2014) found that fostering children out was associated with higher reproductive success for mothers (i.e., a greater number of surviving children), but was associated with an increased risk of stunting and being underweight for foster children. Consistent with the notion that fostering entails some cost to children, several studies have also reported that fostered children are less likely to be enrolled in school (Roby, Erickson, and Nagaishi 2016; Assaad, Levison, and Zibani 2010; Moyi 2010; Novella 2018; Urassa et al. 1997).

However, there is also considerable evidence that foster children may not always be disadvantaged, particularly when fostered by close kin, as is most common across sub-Saharan Africa (Monasch and Boerma 2004). Studies in several countries have found that children fostered by grandparents and other close relatives are not disadvantaged, but that fosterage by more distant kin or nonrelatives is associated with a lower probability of school enrolment (Chuong and Operario 2012; Fleisch, Shindler, and Perry 2012; Ainsworth, Beegle, and Koda 2002; Parker and Short 2009; Shapiro and Tambashe 2001; Madhavan et al. 2017; Burke and Beegle 2004). Multiple studies in northern Tanzania have found that fostered children are not disadvantaged in terms of mortality, anthropometric scores, or educational investment compared to biological children (Urassa et al. 1997; Burke and Beegle 2004; Lawson et al. 2017). In Mozambique, fostered children were not less likely to attend school than biological children within the same household (Lopus 2017). These studies suggest that fostering children need not always come at the cost of a child's well-being. Indeed, some studies have highlighted that being fostered into wealthier or urban households can actually facilitate access to schooling, and may benefit children more than remaining with their parents (Eloundou-Enyegue and Stokes 2002; Zimmerman 2003; Akresh 2004).

\subsection{Why care for foster children?}

Therefore, in certain circumstances, both biological parents and children may benefit from fostering arrangements. Two explanations have been suggested for why foster parents may also benefit from investing in children other than their own biological offspring. First, fostering a genetically related child may increase a foster parent's 
inclusive fitness, i.e., the probability of genetic representation in future generations (Hamilton 1964). This explanation is supported by the fact that traditional forms of fostering are almost always confined to close biological kin (Franklin and Volk 2016; Silk 1980). It is also consistent with the findings described above indicating that foster children's well-being is most likely to be unaffected when they reside with close, as opposed to distant kin (Franklin and Volk 2016). However, genetic relatedness is still higher between biological parents and child, compared to that between grandparents and grandchild, or aunt/uncle and niece/nephew. Therefore, this explanation cannot completely explain why the well-being of fostered children is often indistinguishable from biological children, who by the same logic should be prioritized within fostering households.

A second, complementary, but to date less well-explored, explanation is that in subsistence contexts where households largely produce their own food, children can work to offset their own costs, and may even be regarded as an economic asset to the fostering household (Abebe 2012). Consistent with this explanation, several ethnographic accounts of fostering have described households recruiting children in order to meet work demands, for example helping older or childless individuals, or assisting with farm work ("purposive fostering" (Hampshire et al. 2015)). Qualitative accounts have suggested that fostered children do bear high workloads, and that this may impact their schooling (Oleke et al. 2007; Hampshire et al. 2015). Other studies have suggested children's work as an explanation for differences in anthropometric measurements between fostered and nonfostered children. In Timor-Leste, foster children were smaller for their age than biological children within the same household, possibly because they have a higher burden of agricultural work (Reghupathy et al. 2012). Among the Himba in Namibia, girls' nutritional status is more severely affected by fostering than boys', possibly because Himba girls are more likely to be fostered to help with household work (Prall and Scelza 2017). Both studies call for more detailed studies of children's time allocation. To date, quantitative studies of fostered children's work patterns have found mixed results in different contexts. Fostered girls in Egypt were found to spend more time doing household chores than girls living with both biological parents (Assaad, Levison, and Zibani 2010). In Ghana sons of the household head did less farm work than fostered boys, while in Nepal the household head's children worked less, though there was no difference in farm work (Bhalotra and Heady 2001; Fafchamps and Wahba 2006). However, in Pakistan foster children actually spent less time doing farm work, while in South Africa, foster children did not spend more time collecting water or wood than children living with their biological parents (Bhalotra and Heady 2001; Zimmerman 2003). This suggests a need for more empirical research from different geographic regions. 


\subsection{Study context and predictions}

Here we investigate the differences between fostered and nonfostered children in educational investment and work, using detailed time allocation data from children in Sukuma households from the Mwanza region of north-western Tanzania. Sukuma households are relatively large compared to neighbouring ethnic groups, with households often containing affinal kin and fostered children, leading to considerable variation in household structure and the relatedness of resident children to household heads (Lawson et al. 2015; Urassa et al. 1997). The Sukuma have a long history of fostering, and children traditionally moved frequently between households (Varkevisser 1973: 87-88). Grandparents are the most common foster parents, and it is more common for children to be fostered by maternal kin than paternal kin. Parental divorce and remarriage are common reasons for fostering in this area, though there are also cases where children live with a stepmother, or less commonly a stepfather (Urassa et al. 1997). Orphanhood in response to HIV mortality has increased in recent years, with a likely corresponding increase in fostering, though declining HIV mortality may begin to reverse this trend (Kishamawe et al. 2015; Kanjala et al. 2012).

The Sukuma are patrilocal, and polygynous marriage is permitted (Hadley 2005). Among the household heads interviewed for this study who were married $(72.6 \%)$, $21.1 \%$ were in a polygynous marriage in the village, and $10.6 \%$ were in a polygynous marriage in the town. While there are some inheritance rights recognised by customary law, in practice inheritance is determined by the circumstances surrounding a particular person's death. Traditionally the oldest son inherited land, but now fathers may divide their fields among their sons due to the scarcity of land (Wijsen and Tanner 2002: 4954; Varkevisser 1973: 35). Marriage is nearly universal, and both divorce and remarriage are common (Boerma et al. 2002).

In this area, the majority of children attend primary school, though progression to secondary school is less common. Despite national-level data suggesting that boys are more likely to be enrolled than girls, in this context enrolment is generally equal, or higher for girls in more rural areas where boys' cattle herding work is less compatible with school attendance (Hedges et al. 2018). Education is compulsory between ages 7 and 14, which generally corresponds to the years of primary education, though late starting and grade repetition mean some primary school children may be older than 14 . Primary school education is free, while at the time of this study (2016 academic year), fees had to be paid for secondary school. Even without school fees, families still pay costs such as uniform, stationery, and exam entry fees. At primary level the language of instruction is Swahili, while at secondary level it is English.

Children are expected to contribute to their households by doing farm work or household chores, and these activities are valued both in their use to children's families, and in teaching important skills. Children work more in more rural households, and 
girls work more than boys. School attendance reduces work, but primarily impacts children's leisure time, indicating that the opportunity costs of education in this area are lower than anticipated. Traditionally households were reliant on farming and cattle herding, living in dispersed homesteads, but livelihoods have now diversified, with many families engaged in petty trading and small businesses.

We test a number of predictions grounded in the expectation that the care of foster children is motivated by both close genetic relatedness and by the economic contributions of children. Our study has some advantages over past studies in that we collected detailed data on multiple measures of educational attainment and time allocation data corresponding to a complete day. Compared to many other anthropological studies of fostering, our sample size is also relatively large $(n=1,273$ children). First, we predict that fostered children will receive less educational investment and do more work than children living with both biological parents. We expect this to be particularly true for those children who are fostered by more distant kin as compared to close kin, since lower genetic relatedness should reduce the incentive for investment. Second, we predict that among fostered children, orphans will be particularly disadvantaged, as they do not have the protection or additional investment of a parent outside the household, and may represent a situation of 'crisis fostering' rather than 'purposive fostering' so that children are less likely to have moved into households that can economically support them.

\section{Methods}

\subsection{Data collection}

Household surveys were conducted in two villages in the Kisesa Health and Demographic Surveillance System (HDSS) (Kishamawe et al. 2015) in the Mwanza region of Tanzania during 2016. Data collection was carried out in two locations within the HDSS, in the most rural village, and the least rural settlement, a small town. This sampling strategy was originally chosen in order to consider the impact of urbanisation on children's time allocation, the subject of a previous publication (Hedges et al. 2018). The target age range was between 7 and 19, the ages of formal schooling in Tanzania. The HDSS provided a sampling frame of all households in both locations with members aged between 7 and 19, from which 550 households were randomly sampled. We collected data on household members, including age, gender, education, and occupation, as well as the household's livelihood and asset ownership. Based on observations made during fieldwork, assets were defined as 'basic' (chair, bed, mosquito net), 'intermediate' (bicycle, radio, sofa, cupboard, clock, or sewing 
machine), or 'high-value' (TV, fridge, or motorbike). This was followed by a set of nine questions pertaining to food security during the past month (Coates, Swindale, and Bilinsky 2007).

For each household member aged 7 to 19 , an additional survey was answered by their parent or guardian, collecting information on their biological parents' vital and marital status, and the educational attainment and enrolment of the child. We collected data on children's residence and parents' vital status and so can distinguish between fostered nonorphans and orphans, but did not collect information on the reasons for children living away from their living parents. We do not have information on how long children have been fostered, or where fostered children's parents live, which might also be associated with different outcomes.

In total, household surveys provided data on 1,387 children. 1,278 children (92.1\%) were then followed up for a time allocation interview; among those who could not be interviewed, 52 children were at boarding school, 48 were travelling, two were ill and seven refused to participate. Five children were excluded from further analysis, three who were married, and two who were employees of their household. Female marriage under age 19 is common in this population and is associated with a higher likelihood of being out of school (Schaffnit et al. 2019; Schaffnit, Urassa, and Lawson 2019). Our sample contained very few married individuals, perhaps because they were viewed as adults and not reported as children during household interviews.

In the time allocation interview, children were first asked whether they had done farm work, herding, or any kind of work for pay (e.g., petty trading, casual labouring, working in a shop) during the past week. The respondent was then shown a diagram with rows for different activities, and columns corresponding to the time of day, from 6 a.m. to $10 \mathrm{p} . \mathrm{m}$. They were asked to describe all the activities they had done on the previous weekday, from when they had woken up until they went to bed, and the diagram was shaded to show the time and duration of all activities. The time allocation data was entered into an Excel spreadsheet and subsequently coded into three broad categories: (i) education (school, tuition, studying); (ii) productive work (household chores, e.g., cleaning, cooking, water and fuel collection), farm work, and market work (e.g., petty trading, working in shop), and (iii) personal or 'leisure time' (playing, resting, eating, bathing) (for more detail on the time allocation data collection see Hedges et al. 2018).

\subsection{Data analysis}

We define foster children as those children who do not currently reside with either biological parent, regardless of the vital status of each parent (i.e., fostered children 
include orphans). Among fostered children, $64.7 \%$ live with a grandparent, $4.8 \%$ with an aunt or uncle, and $1.8 \%$ with a sibling or half-sibling; these are classed as living with 'close kin'. We do not collect more detailed data on relatedness, for example whether grandparents are matrilateral or patrilateral, or whether children have been fostered together with or separately from their siblings. The $25.4 \%$ of fostered children living with other relatives are classed as living with 'distant kin,' The small number of children living with nonrelatives $(\mathrm{n}=11)$ precluded analysing them separately, and so they were grouped with 'distant kin.'

Data on parental vital status were used to classify children as a nonorphan, maternal orphan, paternal orphan, or double orphan. For some children their father's (28 children), mother's ( 2 children), or both parents' ( 2 children) vital status was unknown. While the reason for not knowing was not recorded, informal observations suggest it tended to be because the child was abandoned at a young age or left with relatives, or because the father had no contact with the family. These children were recorded as orphans (father unknown as paternal orphan, mother unknown as maternal orphan, and neither parent known as double orphan) on the basis that they also receive no investment from that parent.

Investment in education was measured using three binary variables reflecting: (i) whether a child is currently enrolled in school; (ii) grade for age, where those who are enrolled in school are coded as 0 if they are below their recommended grade and 1 if they are at the correct grade or above, based on the school start age of seven; and (iii) progression to secondary school ('progressed'), where those aged 14 or over are coded as 0 if they are still enrolled in primary school or have dropped out of school, and 1 if they are or have been enrolled in secondary school.

Time allocation to work was measured in two ways. First, two binary variables reflect (i) whether a child had done farm work in the previous week, and (ii) whether a child had done paid work during the previous week. The survey did not collect data on household work done over the past week, as pilot work indicated that the overwhelming majority of children engaged in at least some household work over the course of a week. Second, time allocation data provide the proportion of time spent in education, leisure or personal activities, and productive work on the previous weekday. These data were only collected for weekdays because children only attend school on weekdays and data collection at weekends was logistically difficult.

For each set of outcomes (education, work during past week, and time allocation on previous weekday), models first examined the impact of child's residence for the full sample of children, controlling for factors associated with both fostering, and education and work, including child's age and gender, residence in town or village, and household food security, size, and assets. In these analyses, we used children living with both parents as the reference category, and test for differences in each outcome (described 
above) between this reference category and four other categories of residence: with mother, with father, fostered by close kin, and fostered by distant kin (note that these categories don't specify how many adults children live with, e.g., living 'with mother' does not imply living with mother alone, as other adults could also be resident in the household). A second set of models was then run for the subsample of fostered children, to investigate whether there were differences between children living with distant versus close kin, and whether there were associations between orphan status and outcome variables.

Multilevel logistic regression was used to consider the relationship between fostering and enrolment, grade for age, and whether or not a child had worked during the past week (where farm work and paid work were analysed separately). These models include a random effect for household. Standard logistic regression was used to consider the relationship between fostering and progression to secondary school (which includes only 14- to 19-year-olds), and also in analyses restricted to fostered children. These analyses are not multilevel, as the reduced sample size means that the number of children per household is small, which can lead to misestimation of parameter values (Clarke 2008). Fractional multinomial logistic regression was used to investigate time allocation on the previous weekday, where the outcome variables are the proportions of time spent in education, leisure or personal activities, productive work, adding up to 1 for each child. This approach models the trade-off between children's work and other activities on a weekday, and accounts for autocorrelation between time uses, as time spent in one activity automatically reduces the time available for other activities (Buis 2017; see also Hedges et al. 2018). All analyses were carried out in Stata version 15.

\section{Results}

\subsection{Descriptive results}

\subsubsection{Comparison of households with and without foster children}

We first compared households with and without fostered children, to determine whether there were any notable differences between them. Households with foster children do not differ from those without foster children in terms of wealth measures, with the exception that they are more likely to own land (Table 1). The main differences are in household size and composition; households with foster children are larger, with more children and more older individuals (age 60 and over) than households that do not contain foster children. Fostering was equally common in the village and town. 
Table 1: Comparison of households with and without foster children

\begin{tabular}{|c|c|c|c|c|}
\hline & \multicolumn{2}{|c|}{ Household has foster children? } & \multirow[b]{2}{*}{ Total } & \\
\hline & No & Yes & & \\
\hline \multirow[t]{2}{*}{$\overline{\mathbf{N}}$} & 265 & 180 & 445 & \\
\hline & N (\%) & N (\%) & N (\%) & $p^{a}$ \\
\hline Location & & & & 0.161 \\
\hline Village & $146(55.1)$ & $87(48.3)$ & $233(52.4)$ & \\
\hline Town & $119(44.9)$ & $93(51.7)$ & $212(47.6)$ & \\
\hline Household farms & & & & 0.210 \\
\hline No & $76(28.7)$ & $42(23.3)$ & $118(26.5)$ & \\
\hline Yes & $189(71.3)$ & $138(76.7)$ & $327(73.5)$ & \\
\hline Household owns cows & & & & 0.370 \\
\hline No & $200(75.5)$ & $129(71.7)$ & $329(73.9)$ & \\
\hline Yes & $65(24.5)$ & $51(28.3)$ & $116(26.1)$ & \\
\hline Household owns land & & & & 0.005 \\
\hline No & $51(19.2)$ & $17(9.4)$ & $68(15.3)$ & \\
\hline Yes & $214(80.8)$ & $163(90.6)$ & $377(84.7)$ & \\
\hline Household assets & & & & 0.668 \\
\hline Higher value & $54(20.4)$ & $42(23.3)$ & $96(21.6)$ & \\
\hline Intermediate value & $161(60.8)$ & $102(56.7)$ & $263(59.1)$ & \\
\hline Basic & $50(18.9)$ & $36(20)$ & $86(19.3)$ & \\
\hline Household is food secure & & & & 0.727 \\
\hline No & $187(71.1)$ & $130(72.6)$ & $317(71.7)$ & \\
\hline \multirow[t]{2}{*}{ Yes } & $76(28.9)$ & $49(27.4)$ & $125(28.3)$ & \\
\hline & Mean (SD) & Mean (SD) & Mean (SD) & $p^{b}$ \\
\hline Household size & $7.2(2.5)$ & $8.2(3.8)$ & $7.6(3.1)$ & $<0.001$ \\
\hline Number of children $<7$ years old & $1.7(1.4)$ & $1.5(1.5)$ & $1.6(1.4)$ & 0.061 \\
\hline Number of children 7-19 years old & $2.7(1.4)$ & $3.6(2.1)$ & $3.1(1.7)$ & $<0.001$ \\
\hline Number of adults $20-59$ years old & $2.6(1.1)$ & $2.6(1.7)$ & $2.6(1.4)$ & 0.955 \\
\hline Number of adults $60+$ years old & $0.1(0.4)$ & $0.5(0.7)$ & $0.3(0.6)$ & $<0.001$ \\
\hline Number of cows & $2.5(0.4)$ & $2.6(0.5)$ & $2.5(0.3)$ & 0.938 \\
\hline Land owned (hectares) & $1.9(0.14)$ & $2.5(0.3)$ & $2.2(0.1)$ & 0.062 \\
\hline Food security score ${ }^{c}$ & $17.8(0.4)$ & $17.7(0.5)$ & $17.8(0.3)$ & 0.862 \\
\hline
\end{tabular}

Note: ${ }^{\mathrm{a}} \mathrm{p}$ chi-squared test; ${ }^{\mathrm{b}} \mathrm{p} \mathrm{t}$-test; ${ }^{\mathrm{c}}$ Higher value indicates household is more food secure.

\subsubsection{Child characteristics}

Approximately half of the children in our sample currently live with both their biological mother and their father, with around a quarter living with one parent only, usually their mother. The remaining quarter (26\%) of children are fostered. Among fostered children, $71 \%(\mathrm{n}=236)$ live with close kin, 214 with a grandparent, 6 with a sibling, and 16 with an aunt or uncle; among the remaining 29\%, 84 live with distant relatives, while 11 live in a nonrelative's household (but may still have other kin resident in the household). Residence varies by child characteristics (Table 2). Girls are 
slightly more likely to be fostered than boys, and older children are more likely to be fostered by distant kin than younger children. Paternal orphans are more likely to live with their mother $(50 \%)$ than maternal orphans are to live with their father $(42 \%)$; maternal orphans are therefore more likely to be fostered than paternal orphans.

Table 2: Child characteristics by residence

\begin{tabular}{|c|c|c|c|c|c|c|}
\hline & \multicolumn{6}{|l|}{ Child lives with } \\
\hline & Both parents & Mother & Father & Close kin & Distant kin & Total \\
\hline$\overline{\mathbf{N}}$ & 638 & 226 & 78 & 236 & 95 & 1,273 \\
\hline Row percentages & $\mathbf{N}(\%)$ & $\mathrm{N}(\%)$ & $\mathrm{N}(\%)$ & $\mathrm{N}(\%)$ & $\mathrm{N}(\%)$ & $\mathbf{N}$ \\
\hline \multicolumn{7}{|l|}{ Gender } \\
\hline Male & $337(53.3)$ & $107(16.9)$ & $35(5.5)$ & $114(18.0)$ & $39(6.2)$ & 632 \\
\hline Female & $301(47.0)$ & $119(18.6)$ & $43(6.7)$ & $122(19.0)$ & $56(8.7)$ & 641 \\
\hline \multicolumn{7}{|l|}{ Age group } \\
\hline 7 to 13 & $416(49.9)$ & $149(17.9)$ & $51(6.1)$ & $177(21.2)$ & $41(4.9)$ & 834 \\
\hline 14 to 19 & $222(50.6)$ & 77 (17.5) & $27(6.2)$ & $59(13.4)$ & $54(12.3)$ & 439 \\
\hline \multicolumn{7}{|l|}{ Orphan status } \\
\hline Nonorphan & $638(60.8)$ & $149(14.2)$ & $63(6.0)$ & $145(13.8)$ & $55(5.2)$ & 1,050 \\
\hline Paternal orphan & - & $77(50.3)$ & - & $54(35.3)$ & $22(14.4)$ & 153 \\
\hline Maternal orphan & - & - & $15(41.7)$ & $16(44.4)$ & $5(13.9)$ & 36 \\
\hline Double orphan & - & - & - & $21(61.8)$ & $13(38.2)$ & 34 \\
\hline Column percentages & $\mathrm{N}(\%)$ & $\mathbf{N}(\%)$ & $\mathbf{N}(\%)$ & $\mathrm{N}(\%)$ & $\mathrm{N}(\%)$ & $\mathbf{N}(\%)$ \\
\hline \multicolumn{7}{|l|}{ Currently enrolled } \\
\hline No & $116(18.2)$ & $45(19.9)$ & $14(17.9)$ & $34(14.4)$ & $33(34.7)$ & $242(19)$ \\
\hline Yes & $522(81.8)$ & $181(80.1)$ & $64(82.1)$ & $202(85.6)$ & $62(65.3)$ & $1,031(81)$ \\
\hline \multicolumn{7}{|l|}{ At correct grade for age } \\
\hline No & $261(47.9)$ & $87(46)$ & $38(56.7)$ & $111(54.7)$ & $41(63.1)$ & $538(50.3)$ \\
\hline Yes & $284(52.1)$ & $102(54)$ & $29(43.3)$ & $92(45.3)$ & $24(36.9)$ & $531(49.7)$ \\
\hline \multicolumn{7}{|c|}{ Progressed to secondary school } \\
\hline No & $114(51.6)$ & $33(43.4)$ & $13(48.1)$ & $29(49.2)$ & $36(67.9)$ & $225(51.6)$ \\
\hline \multirow[t]{2}{*}{ Yes } & $107(48.4)$ & $43(56.6)$ & $14(51.9)$ & $30(50.8)$ & $17(32.1)$ & $211(48.4)$ \\
\hline & Mean (SD) & Mean (SD) & Mean (SD) & Mean (SD) & Mean (SD) & Mean (SD) \\
\hline \multicolumn{7}{|l|}{ Mean hours spent in } \\
\hline Education & $5.9(4.3)$ & $6.1(4.4)$ & $5.9(4.4)$ & $6.2(4.3)$ & $4.4(4.6)$ & $5.9(4.3)$ \\
\hline Leisure & $9.5(3.5)$ & $9.7(3.7)$ & $9.7(3.6)$ & $9.6(3.3)$ & $10(3.7)$ & $9.6(3.5)$ \\
\hline Chores & $2.2(2.4)$ & $2.1(1.9)$ & $2.5(2.6)$ & $2.1(2.3)$ & $3.2(3.1)$ & $2.3(2.4)$ \\
\hline Farm work & $1.2(2.6)$ & $1(2.6)$ & $0.8(1.9)$ & $1.1(2.5)$ & $1(2.3)$ & $1.1(2.5)$ \\
\hline Market work & $0.2(1.2)$ & $0.1(1)$ & $0.1(0.6)$ & $0.1(0.9)$ & $0.4(1.6)$ & $0.2(1.1)$ \\
\hline Total work & $3.6(3.3)$ & $3.2(3.1)$ & $3.4(3.2)$ & $3.3(3.1)$ & $4.6(3.7)$ & $3.5(3.3)$ \\
\hline
\end{tabular}

\subsection{Educational outcomes}

The relationship between fostering and education outcomes is dependent on whether children are fostered by close or distant kin. Children fostered by close kin do not differ 
from children living with both biological parents in terms of either enrolment or progression to secondary school (Table 3; Figure 1). However, they do have lower odds of being at the correct grade for age. This is consistent with past disruption to schooling associated with the factors leading to fostering, for example parental death or economic hardship. It may also reflect lower levels of investment, or lower-quality investment in child education, resulting in a child being behind in school. Children fostered by more distant kin, on the other hand, experience relatively poor educational outcomes across all three measures compared to children living with both parents (Table 3; Figure 1). Among children living with just one biological parent, we also observe that children living only with their father have the lowest odds of being at the correct grade for age.

Figure 1: Predicted probability of educational outcomes by child residence (predicted probabilities from Model 1 in Table 3; 95\% confidence intervals; control variables are mean centred)

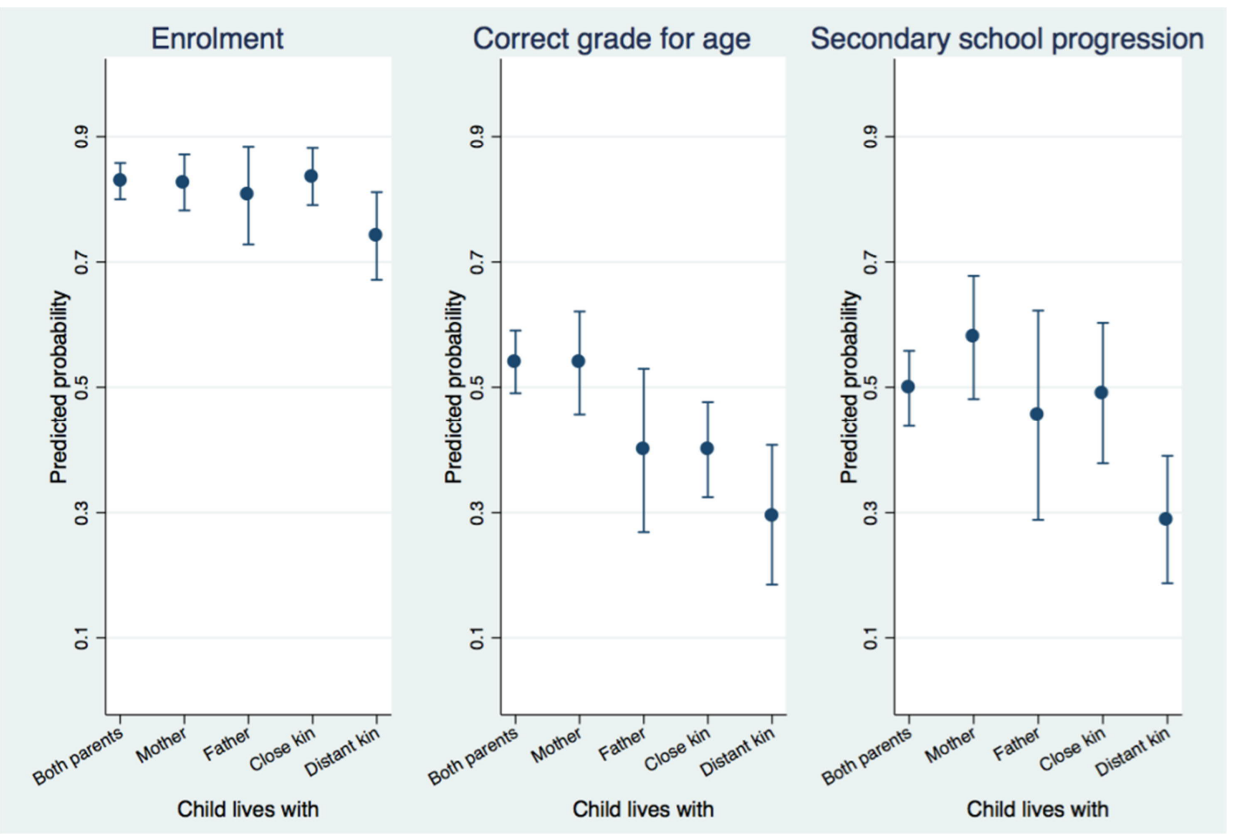


Table 3: Summary of logistic regression analysis predicting (1) enrolment $(n=1,256)$, grade for age $(n=1,053)$, and progression to secondary school $(n=432)$ for all children, and (2) enrolment $(n=326)$, grade for age $(n=263)$ and progression to secondary school $(n=111)$ among fostered children only

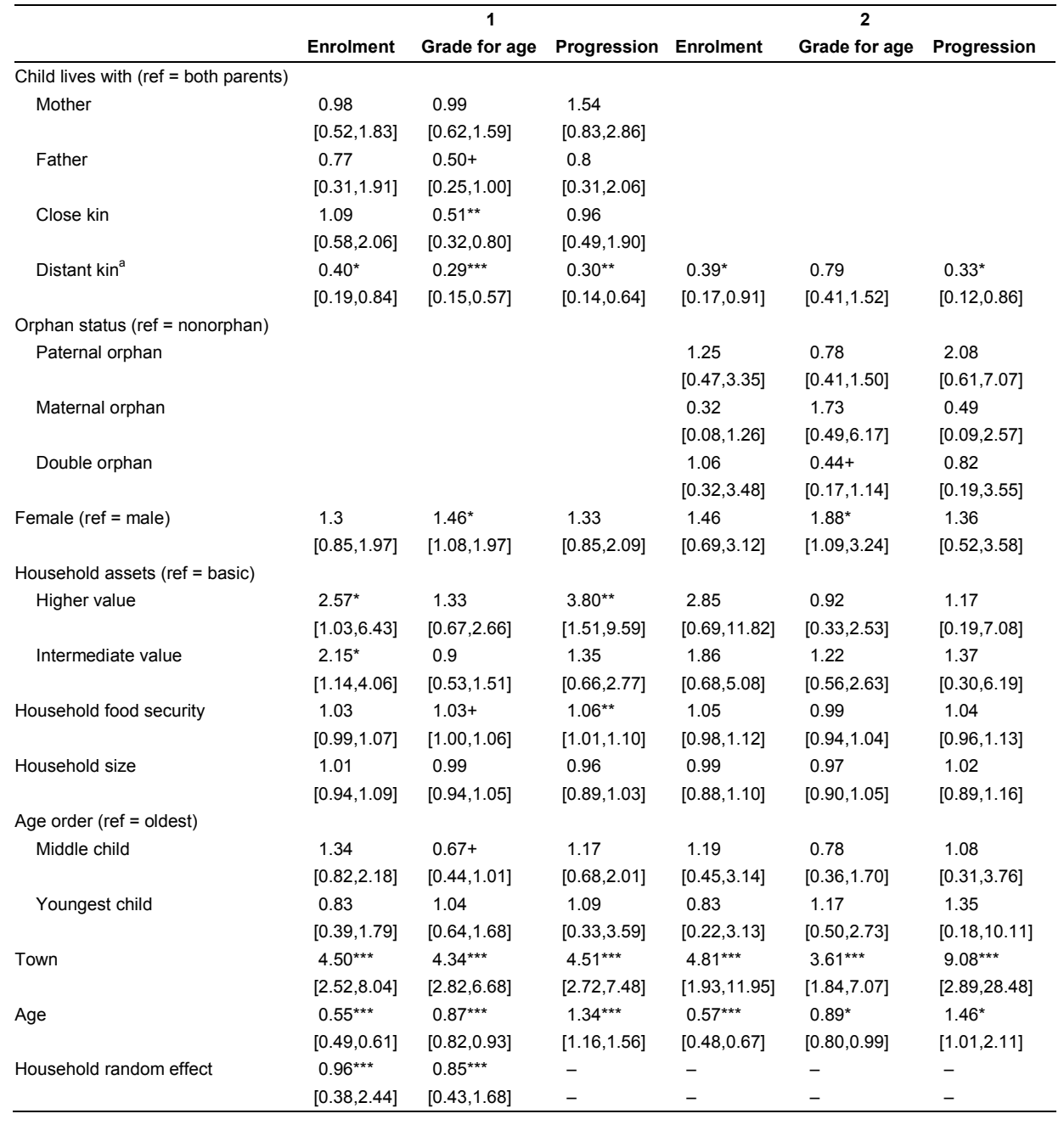

Note: ${ }^{a}$ For second set of models, the reference category for distant kin is close kin. Data shown are odd ratios (exponentiated coefficients); $95 \%$ confidence intervals in brackets. $+p<0.10,{ }^{*} p<0.05,{ }^{\star \star} p<0.01,{ }^{\star \star \star} p<0.001$. 
We predicted that among fostered children, orphans would be most disadvantaged as they are likely to receive reduced or nonexistent parental investment. We therefore investigated whether being an orphan accounts for some of the educational disadvantage seen among fostered children. There is suggestive evidence (i.e., $\mathrm{p}<0.1$ ) that double orphans have lower odds of being at the correct grade for age, perhaps reflecting greater disruption to their studies as a result of two parental deaths. Results for maternal and paternal orphans were variable in direction and not statistically significant. An additional finding from the fostered-only model is that children fostered by distant kin have lower odds of all educational outcomes compared to those fostered by close kin.

\subsection{Farm and paid work during past week}

Compared to children living with both parents, fostered children were more likely to report having done farm work during the past week (Table 4, Model 1; Figure 2). However, there was no evidence of an association between fostering and paid work, though the prevalence of paid work is very low overall in this context. Among fostered children (Table 4, Model 2), there is no evidence that those fostered by distant kin are more likely to have worked than those fostered by close kin. Contrary to our predictions, orphans are actually less likely to have worked in the past week compared to nonorphans, though this effect is not statistically significant other than for paternal orphans. 
Table 4: $\quad$ Summary of logistic regression analyses predicting (1) farm work and paid work during past week $(n=1,256)$ for all children and (2) farm work and paid work during past week $(n=326)$ among fostered children only

\begin{tabular}{|c|c|c|c|c|}
\hline & \multicolumn{2}{|r|}{1} & \multicolumn{2}{|r|}{2} \\
\hline & Farm work & Paid work & Farm work & Paid work \\
\hline \multicolumn{5}{|c|}{ Child lives with (ref = both parents) } \\
\hline \multirow[t]{2}{*}{ Mother } & 1.03 & 0.79 & & \\
\hline & {$[0.61,1.74]$} & {$[0.37,1.69]$} & & \\
\hline \multirow[t]{2}{*}{ Father } & 1.03 & 1.04 & & \\
\hline & {$[0.47,2.27]$} & {$[0.35,3.10]$} & & \\
\hline \multirow[t]{2}{*}{ Close kin } & $1.93^{*}$ & 1.39 & & \\
\hline & {$[1.16,3.22]$} & {$[0.72,2.71]$} & & \\
\hline \multirow[t]{2}{*}{ Distant kin ${ }^{a}$} & $2.09^{*}$ & 1.25 & 1.06 & 1.13 \\
\hline & {$[1.07,4.06]$} & {$[0.55,2.87]$} & {$[0.56,2.00]$} & {$[0.44,2.90]$} \\
\hline \multicolumn{5}{|c|}{ Orphan status (ref = nonorphan) } \\
\hline \multirow[t]{2}{*}{ Paternal orphan } & & & $0.49^{*}$ & 0.61 \\
\hline & & & {$[0.25,0.97]$} & {$[0.21,1.75]$} \\
\hline \multirow[t]{2}{*}{ Maternal orphan } & & & 0.67 & 0.8 \\
\hline & & & {$[0.22,2.02]$} & {$[0.16,4.04]$} \\
\hline \multirow[t]{2}{*}{ Double orphan } & & & 0.59 & 1.2 \\
\hline & & & {$[0.22,1.54]$} & {$[0.35,4.10]$} \\
\hline \multirow[t]{2}{*}{ Female $($ ref $=$ male $)$} & $0.31^{* * *}$ & 0.86 & $0.27^{\star \star *}$ & 0.97 \\
\hline & {$[0.22,0.43]$} & {$[0.53,1.39]$} & {$[0.15,0.46]$} & {$[0.43,2.16]$} \\
\hline \multicolumn{5}{|c|}{ Household assets (ref = basic) } \\
\hline \multirow[t]{2}{*}{ Higher value } & 0.7 & 1.41 & 1.25 & 0.44 \\
\hline & {$[0.31,1.59]$} & {$[0.52,3.80]$} & {$[0.44,3.54]$} & {$[0.12,1.68]$} \\
\hline \multirow[t]{2}{*}{ Intermediate value } & 1.22 & 0.98 & 1.12 & $0.15^{\star \star}$ \\
\hline & {$[0.69,2.15]$} & {$[0.45,2.12]$} & {$[0.54,2.34]$} & {$[0.05,0.50]$} \\
\hline \multirow[t]{2}{*}{ Household food security } & $0.96^{*}$ & 0.96 & 0.96 & 1.01 \\
\hline & {$[0.93,1.00]$} & {$[0.92,1.01]$} & {$[0.92,1.01]$} & {$[0.93,1.08]$} \\
\hline \multirow[t]{2}{*}{ Household size } & 1.01 & 1.03 & 1 & 1.03 \\
\hline & {$[0.95,1.08]$} & {$[0.95,1.12]$} & {$[0.93,1.08]$} & {$[0.92,1.15]$} \\
\hline \multicolumn{5}{|l|}{ Age order $($ ref $=$ oldest $)$} \\
\hline \multirow[t]{2}{*}{ Middle child } & 1.42 & 0.71 & $2.32^{*}$ & 1.09 \\
\hline & {$[0.93,2.18]$} & {$[0.39,1.30]$} & {$[1.08,4.96]$} & {$[0.38,3.14]$} \\
\hline \multirow[t]{2}{*}{ Youngest child } & 1.13 & 0.76 & 1.73 & 0.91 \\
\hline & {$[0.66,1.95]$} & {$[0.32,1.78]$} & {$[0.69,4.35]$} & {$[0.24,3.51]$} \\
\hline \multirow[t]{2}{*}{ Town (ref = village) } & $0.08^{* \star \star}$ & 1.53 & $0.15^{\star \star *}$ & $2.58+$ \\
\hline & {$[0.05,0.14]$} & {$[0.84,2.81]$} & {$[0.08,0.29]$} & {$[0.92,7.23]$} \\
\hline \multirow[t]{2}{*}{ Age } & $1.25^{\star \star \star}$ & $1.19^{\star \star \star}$ & $1.28^{\star \star \star}$ & $1.16+$ \\
\hline & {$[1.17,1.33]$} & {$[1.08,1.30]$} & {$[1.14,1.42]$} & {$[0.99,1.35]$} \\
\hline \multirow[t]{2}{*}{ Household random effect } & $1.55^{\star \star \star}$ & $0.86^{\star \star}$ & - & - \\
\hline & {$[0.92,2.61]$} & {$[0.25,2.94]$} & & \\
\hline
\end{tabular}

Note: ${ }^{a}$ For second set of models, the reference category for distant kin is close kin. Data shown is odd ratios (exponentiated coefficients); $95 \%$ confidence intervals in brackets. $+p<0.10,{ }^{*} p<0.05,{ }^{* *} p<0.01,{ }^{* * *} p<0.001$. 
Figure 2: Predicted probability of doing farm work and paid work during past week, by child residence (predicted probabilities from Model 1 in Table 4; 95\% confidence intervals; control variables are mean centred)

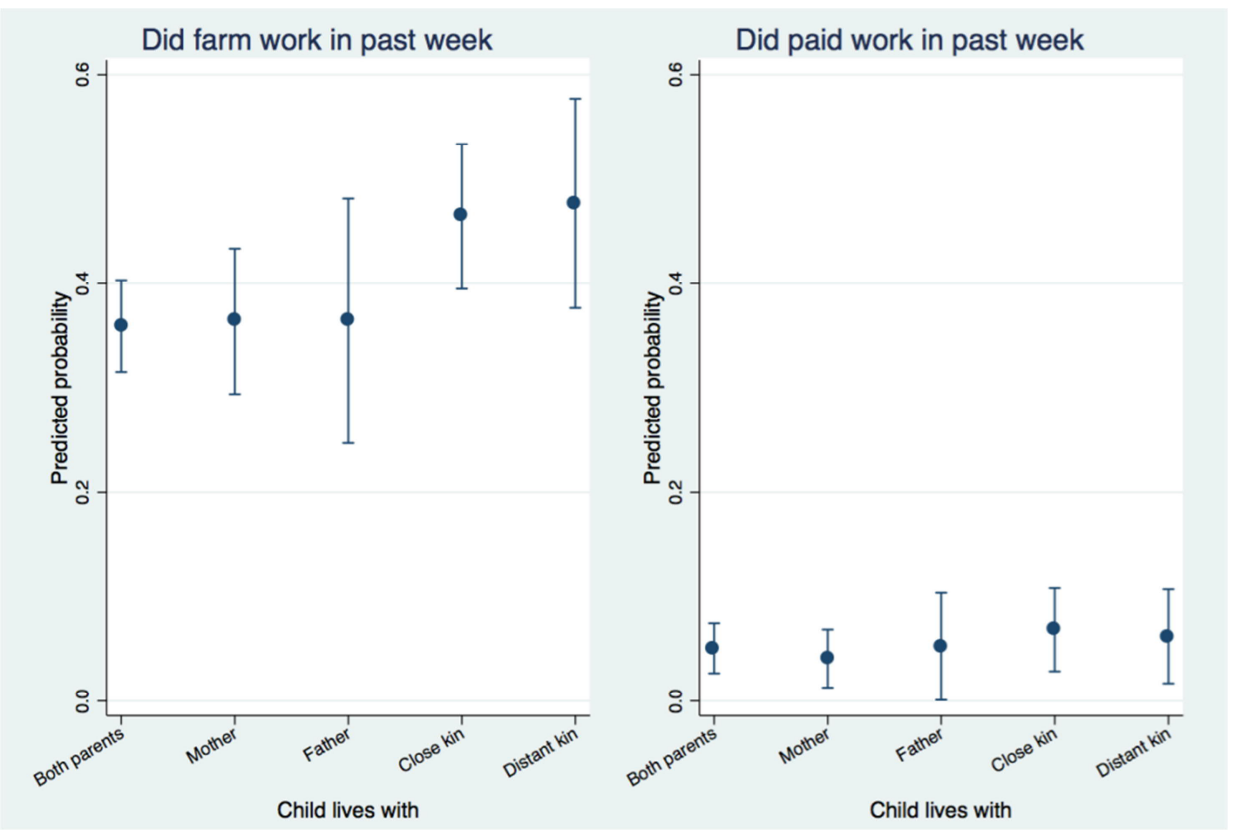

\subsection{Trade-off between work and education}

Finally, we also investigated children's time allocation on the previous weekday according to residence and orphan status, to determine whether fostered or orphaned children work more on weekdays, and whether this work trades off with time allocated to schooling. Table 5 shows each trade-off in time use, i.e., between leisure and education, leisure and work, and work and education, from fractional multinomial logistic regression models. These are the relative differences; a negative coefficient indicates a reduction in time spent in that activity relative to the other activity, while a positive coefficient indicates an increase in time. For example, in the first column we see that children living with distant kin spend more time in leisure relative to education, and more time in work relative to education, compared to children living with both parents. From Table 5, it therefore seems that those living with distant kin spend more 
time in leisure and work relative to the time they spend in education, compared to those living with one or both parents. However, these results can only tell us about the effect of residence on the relationship between pairs of activities. The marginal effects from these models show the effect of residence on the relationship between all three activities. Figure 3 shows the absolute difference in hours of education, leisure and work between nonfostered and fostered children. Zero represents the reference category of children living with both parents; confidence intervals which cross zero indicate a nonsignificant difference. Children fostered by distant kin spend less time in education than nonfostered children and appear to trade this off with more time spent in leisure. There is a suggestion that they spend more time in work also, though this difference does not reach statistical significance $(p=0.233)$. No other differences in time allocation are apparent, with the exception that those living with just their mother spend slightly less time working than those living with both biological parents.

Figure 3: Difference between nonfostered and fostered children in hours spent in education, leisure, and work on previous weekday $(n=1,256)$, from fractional multinomial logistic regression models adjusting for child age, gender, age order, town residence, household food security, assets, and size, and interviews done on a Monday

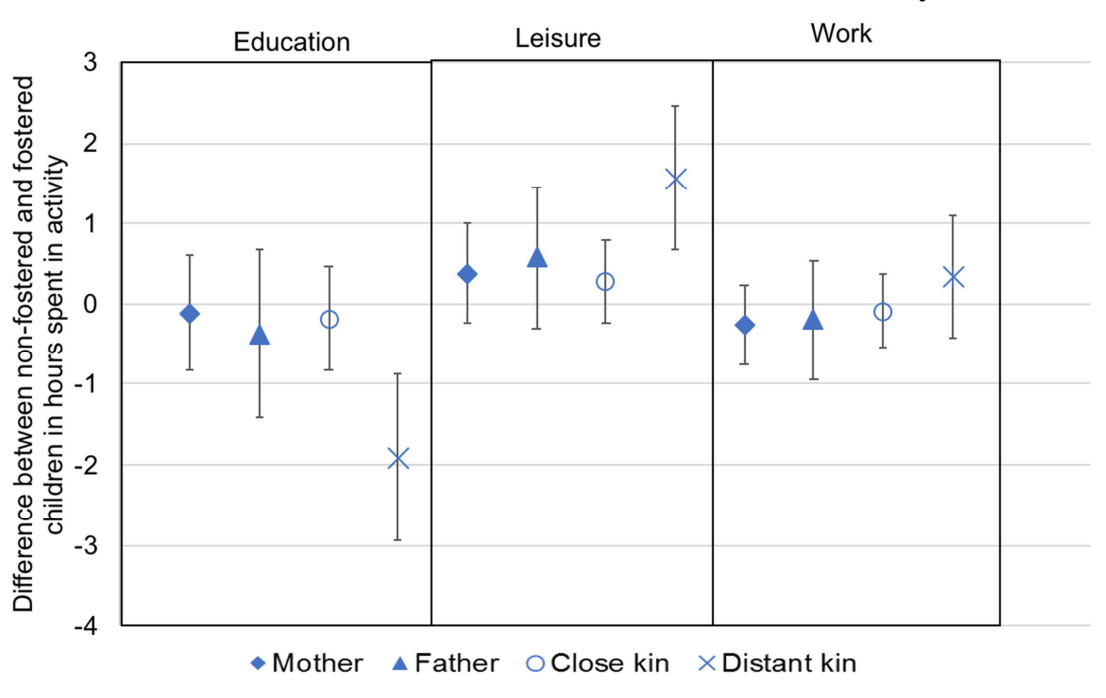


Hedges et al.: Earning their keep? Fostering, children's education, and work in north-western Tanzania

Table 5: $\quad$ Summary of fractional multinomial logistic regression analyses for (1) the association between child residence and time allocation $(n=1,256)$ and $(2)$ the association between child residence, orphan status, and time allocation $(n=326)$

\begin{tabular}{|c|c|c|c|c|c|c|}
\hline & \multicolumn{3}{|c|}{1} & \multicolumn{3}{|c|}{2} \\
\hline & $\begin{array}{l}\text { Change in } \\
\text { leisure from } \\
\text { education }\end{array}$ & $\begin{array}{l}\text { Change in work } \\
\text { from education }\end{array}$ & $\begin{array}{l}\text { Change in work } \\
\text { from leisure }\end{array}$ & $\begin{array}{l}\text { Change in } \\
\text { leisure from } \\
\text { education }\end{array}$ & $\begin{array}{l}\text { Change in work } \\
\text { from education }\end{array}$ & $\begin{array}{l}\text { Change in work } \\
\text { from leisure }\end{array}$ \\
\hline \multicolumn{7}{|c|}{ Child residence (ref $=$ both parents) } \\
\hline Mother & $\begin{array}{l}0.06 \\
{[-0.12,0.24]}\end{array}$ & $\begin{array}{l}-0.06 \\
{[-0.3,0.19]}\end{array}$ & $\begin{array}{l}-0.12 \\
{[-0.29,0.05]}\end{array}$ & & & \\
\hline Father & $\begin{array}{l}0.12 \\
{[-0.14,0.39]}\end{array}$ & $\begin{array}{l}0.01 \\
{[-0.36,0.38]}\end{array}$ & $\begin{array}{l}-0.12 \\
{[-0.37,0.14]}\end{array}$ & & & \\
\hline Close kin & $\begin{array}{l}0.06 \\
{[-0.1,0.22]}\end{array}$ & $\begin{array}{l}0.01 \\
{[-0.22,0.23]}\end{array}$ & $\begin{array}{l}-0.05 \\
{[-0.2,0.1]}\end{array}$ & & & \\
\hline Distant kin ${ }^{a}$ & $\begin{array}{l}0.55^{\star \star} \\
{[0.23,0.87]}\end{array}$ & $\begin{array}{l}0.5^{*} \\
{[0.09,0.9]}\end{array}$ & $\begin{array}{l}-0.06 \\
{[-0.29,0.18]}\end{array}$ & $\begin{array}{l}0.51^{* *} \\
{[0.15,0.86]}\end{array}$ & $\begin{array}{l}0.61^{* *} \\
{[0.17,1.05]}\end{array}$ & $\begin{array}{l}0.11 \\
{[-0.15,0.36]}\end{array}$ \\
\hline \multicolumn{7}{|c|}{ Orphan status $($ ref $=$ nonorphan $)$} \\
\hline Maternal orphan & & & & $\begin{array}{c}0.42 \\
{[-0.22,1.06]}\end{array}$ & $\begin{array}{l}0.83^{*} \\
{[0.05,1.61]}\end{array}$ & $\begin{array}{l}0.41^{\star} \\
{[0.07,0.76]}\end{array}$ \\
\hline Paternal orphan & & & & $\begin{array}{l}-0.01 \\
{[-0.31,0.3]}\end{array}$ & $\begin{array}{l}-0.06 \\
{[-0.47,0.36]}\end{array}$ & $\begin{array}{l}-0.05 \\
{[-0.35,0.25]}\end{array}$ \\
\hline Double orphan & & & & $\begin{array}{c}0.43+ \\
{[-0.08,0.94]}\end{array}$ & $\begin{array}{c}0.31 \\
{[-0.35,0.96]}\end{array}$ & $\begin{array}{l}-0.12 \\
{[-0.45,0.2]}\end{array}$ \\
\hline Female $($ ref $=$ male $)$ & $\begin{array}{l}-0.22^{\star \star \star} \\
{[-0.34,-0.1]}\end{array}$ & $\begin{array}{l}0.02 \\
{[-0.15,0.19]}\end{array}$ & $\begin{array}{l}0.24^{* * *} \\
{[0.13,0.36]}\end{array}$ & $\begin{array}{l}-0.1 \\
{[-0.35,0.15]}\end{array}$ & $\begin{array}{l}0.02 \\
{[-0.33,0.37]}\end{array}$ & $\begin{array}{l}0.12 \\
{[-0.11,0.35]}\end{array}$ \\
\hline \multicolumn{7}{|c|}{ Household assets (ref $=$ basic) } \\
\hline Intermediate & $\begin{array}{l}-0.13 \\
{[-0.31,0.06]}\end{array}$ & $\begin{array}{l}-0.24+ \\
{[-0.49,0.01]}\end{array}$ & $\begin{array}{l}-0.11 \\
{[-0.27,0.05]}\end{array}$ & $\begin{array}{l}-0.06 \\
{[-0.39,0.26]}\end{array}$ & $\begin{array}{l}-0.31 \\
{[-0.8,0.17]}\end{array}$ & $\begin{array}{l}-0.25+ \\
{[-0.54,0.04]}\end{array}$ \\
\hline Higher value & $\begin{array}{l}-0.15 \\
{[-0.4,0.1]}\end{array}$ & $\begin{array}{l}-0.42^{*} \\
{[-0.76,-0.08]}\end{array}$ & $\begin{array}{l}-0.27^{\star} \\
{[-0.5,-0.05]}\end{array}$ & $\begin{array}{l}0.08 \\
{[-0.38,0.54]}\end{array}$ & $\begin{array}{l}-0.25 \\
{[-0.88,0.38]}\end{array}$ & $\begin{array}{l}-0.33+ \\
{[-0.71,0.05]}\end{array}$ \\
\hline $\begin{array}{l}\text { Household food } \\
\text { security }\end{array}$ & $\begin{array}{l}-0.01^{*} \\
{[-0.02,0]}\end{array}$ & $\begin{array}{l}-0.01+ \\
{[-0.03,0]}\end{array}$ & $\begin{array}{l}0 \\
{[-0.01,0.01]}\end{array}$ & $\begin{array}{l}-0.02 \\
{[-0.04,0.01]}\end{array}$ & $\begin{array}{l}-0.03+ \\
{[-0.06,0]}\end{array}$ & $\begin{array}{l}-0.01 \\
{[-0.03,0.01]}\end{array}$ \\
\hline Household size & $\begin{array}{l}0.04^{* *} \\
{[0.02,0.06]}\end{array}$ & $\begin{array}{l}0.04^{*} \\
{[0.01,0.07]}\end{array}$ & $\begin{array}{c}0 \\
{[-0.02,0.02]}\end{array}$ & $\begin{array}{r}0.04+ \\
{[0,0.08]}\end{array}$ & $\begin{array}{l}0.02 \\
{[-0.03,0.08]}\end{array}$ & $\begin{array}{l}-0.02 \\
{[-0.05,0.02]}\end{array}$ \\
\hline \multicolumn{7}{|c|}{ Age order $($ ref $=$ oldest $)$} \\
\hline Middle child & $\begin{array}{l}-0.33^{\star \star \star} \\
{[-0.51,-0.16]}\end{array}$ & $\begin{array}{l}-0.4^{\star *} \\
{[-0.63,-0.17]}\end{array}$ & $\begin{array}{l}-0.06 \\
{[-0.21,0.08]}\end{array}$ & $\begin{array}{l}-0.44^{\star} \\
{[-0.84,-0.04]}\end{array}$ & $\begin{array}{l}-0.42+ \\
{[-0.91,0.07]}\end{array}$ & $\begin{array}{l}0.02 \\
{[-0.25,0.29]}\end{array}$ \\
\hline Youngest child & $\begin{array}{l}0.03 \\
{[-0.17,0.22]}\end{array}$ & $\begin{array}{l}-0.19 \\
{[-0.45,0.08]}\end{array}$ & $\begin{array}{l}-0.21^{*} \\
{[-0.4,-0.03]}\end{array}$ & $\begin{array}{l}-0.07 \\
{[-0.5,0.36]}\end{array}$ & $\begin{array}{l}-0.26 \\
{[-0.86,0.34]}\end{array}$ & $\begin{array}{l}-0.19 \\
{[-0.59,0.21]}\end{array}$ \\
\hline Town (ref = village) & $\begin{array}{l}-0.38^{\star \star \star} \\
{[-0.52,-0.23]}\end{array}$ & $\begin{array}{l}-0.68^{* \star *} \\
{[-0.88,-0.48]}\end{array}$ & $\begin{array}{l}-0.3^{\star \star \star} \\
{[-0.45,-0.16]}\end{array}$ & $\begin{array}{l}-0.61^{\text {***}} \\
{[-0.91,-0.31]}\end{array}$ & $\begin{array}{l}-0.84^{\star \star \star} \\
{[-1.26,-0.41]}\end{array}$ & $\begin{array}{l}-0.23+ \\
{[-0.49,0.04]}\end{array}$ \\
\hline Child age & $\begin{array}{c}0 \\
{[-0.02,0.03]}\end{array}$ & $\begin{array}{l}0.11^{* \star *} \\
{[0.08,0.14]}\end{array}$ & $\begin{array}{l}0.11^{\text {***}} \\
{[0.09,0.13]}\end{array}$ & $\begin{array}{l}-0.02 \\
{[-0.07,0.03]}\end{array}$ & $\begin{array}{l}0.09^{\star \star} \\
{[0.02,0.15]}\end{array}$ & $\begin{array}{l}0.11^{\star \star \star} \\
{[0.06,0.15]}\end{array}$ \\
\hline $\begin{array}{l}\text { Monday interview } \\
\text { (ref = other day) }\end{array}$ & $\begin{array}{l}-0.16^{\star} \\
{[-0.31,-0.02]}\end{array}$ & $\begin{array}{l}-0.21^{*} \\
{[-0.42,-0.01]}\end{array}$ & $\begin{array}{l}-0.05 \\
{[-0.19,0.09]}\end{array}$ & $\begin{array}{l}-0.13 \\
{[-0.42,0.17]}\end{array}$ & $\begin{array}{l}-0.07 \\
{[-0.47,0.33]}\end{array}$ & $\begin{array}{c}0.06 \\
{[-0.19,0.3]}\end{array}$ \\
\hline Constant & $\begin{array}{l}0.85^{\star \star \star} \\
{[0.42,1.28]}\end{array}$ & $\begin{array}{l}-1.29^{\star \star \star} \\
{[-1.87,-0.7]}\end{array}$ & $\begin{array}{l}-2.13^{\star \star \star} \\
{[-2.55,-1.72]}\end{array}$ & $\begin{array}{l}1.22^{*} \\
{[0.29,2.16]}\end{array}$ & $\begin{array}{l}-0.56 \\
{[-1.66,0.54]}\end{array}$ & $\begin{array}{l}-1.79^{* * *} \\
{[-2.51,-1.06]}\end{array}$ \\
\hline
\end{tabular}

Note: ${ }^{a}$ For second set of models, the reference category for distant kin is close kin. $+p<0.10,{ }^{*} p<0.05,{ }^{* *} p<0.01,{ }^{* * *} p<0.001$.

Figure 4 shows the difference between orphaned and nonorphaned children among fostered children only. A number of differences are notable. Double orphans spend less time in education and have more leisure time than children with living parents, but do 
not appear to work more. Maternal orphans spend more time working than children living with both parents, trading this off against marginally reduced time in education and leisure. Paternal orphans do not appear to differ from nonorphans in their time allocation. Those fostered by distant kin spend more time in leisure and work, and less time in education, relative to those fostered by close kin (Table 5, Model 2).

Figure 4: Among fostered children only $(n=326)$, difference between orphaned and nonorphaned foster children in hours spent in education, leisure, and work on previous weekday, from fractional multinomial logistic regression models adjusting for child age, gender, residence with distant kin, age order, town residence, household food security, assets, and size, and for interviews done on a Monday

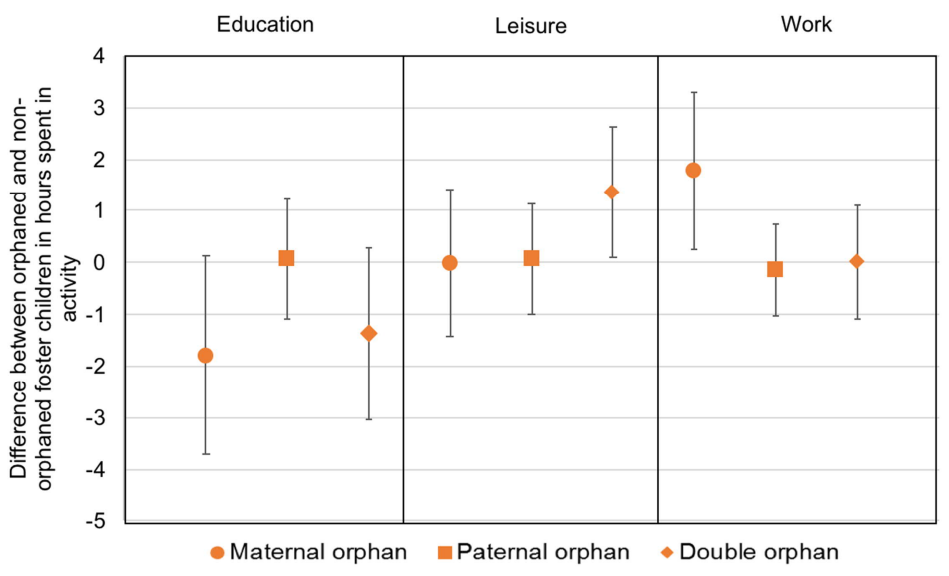

\section{Discussion}

Our results suggest that both genetic relatedness and children's work contributions play an important role in explaining variation in child time allocation and education among fostered children. The large majority of fostered children in this society live with close kin and, in line with previous studies of fostering in Tanzania (Ainsworth, Beegle, and Koda 2002; Burke and Beegle 2004), children fostered with close kin receive similar levels of educational investment as children living with their biological parents. It is only when living with distant kin that fostered children experience lower odds of school enrolment and progression to secondary school. We also find that children fostered by 
either close kin or distant kin are more likely to report doing farm work in the previous week than other children, although we detect no differences between fostered and nonfostered children in time allocation to work when reporting on the previous weekday. This is likely to be because the previous week variable captures farm work done on weekends; it may be that foster children's time is protected during the week when they attend school, but that they are more likely to work at weekends. These findings, combined with the observation that children are active producers in this population (see Hedges et al. 2018), suggest that children's work contributions may be important in offsetting some of the costs to their foster households. While the impact of foster children's work on their schooling may be limited, there may be other consequences, for example other studies have suggested that foster children's workload may negatively impact their nutritional status due to higher energetic requirements (Prall and Scelza 2017; Reghupathy et al. 2012).

There are few differences between the characteristics of households with and without foster children (see also Lawson et al. 2017). However, households fostering children are more likely to own land and have more older individuals (aged 60 and over) who may be less able to contribute to household work, which is consistent with a greater demand for children's work. In informal discussions during data collection, household members said fostering was most often done by grandparents, particularly grandmothers, who wanted company or help with household work, or children living with relatives in order to attend school, suggesting that purposive fostering, where households actively foster children in, is common in this context. Households fostering children are larger but not more wealthy or food secure. Without longitudinal data we cannot tell what effect fostering has on households, though other studies have suggested that the circulation of children between households may reduce wealth differentials between households and even out the labour supply (Serra 2009; Goody 1982).

While time allocation to work activities on school days did not show significant differences between fostered and nonfostered children, children fostered with distant kin spent less time in educational activities. For these children, time spent in education appears to trade-off primarily with leisure rather than work activities, suggesting that distant kin may be less willing to pay school expenses, as opposed to requiring greater work inputs, which then impacts school attendance. Increased leisure time may also indicate that distant kin do not provide as much supervision or monitoring as closer kin. Qualitative interviews with teachers, parents, and adolescents from the local area indicate that parental supervision and interest is important in ensuring children attend school and stay motivated, and it may be this input that distant kin are particularly unwilling or unable to provide. However, we must also consider the possibility that children fostered by distant kin may be different from those fostered by close kin. During data collection and in the qualitative interviews, we heard a few cases of parent- 
child conflict over schooling, with some adolescents wishing to drop out of school, and so running away from home to avoid going. Some of those living with distant kin may therefore be fostered because they do not want to be enrolled in school, as opposed to being less likely to be enrolled because they are fostered.

Parental death has historically been a relatively uncommon reason for children being fostered in sub-Saharan Africa (Gaydosh 2015), and in northern Tanzania specifically, accounts for a minority of cases where children live away from their parents (Lawson et al. 2017). We anticipated that orphans represent a situation of 'crisis fostering' and would therefore be particularly disadvantaged among fostered children. However, we find little evidence of this. Double orphans are marginally less likely to be at the correct grade for their age, perhaps reflecting greater disruption to their schooling as the result of both parents having died. This presumably accounts for them spending less time in education on weekdays, as at a given age, they are at a lower grade and so spend less time in school. However, this does not seem to result in them spending more time working. Paternal orphans do not differ from other fostered children on educational measures or time allocation, although they do appear to be less likely to do farm work in the previous week. Maternal orphans, on the other hand, do appear to work slightly more on weekdays, and this marginally reduces their time spent in education and leisure.

These patterns fit with previous research which has consistently shown that paternal orphans tend to show fewer deficits to their well-being than maternal orphans (Coall and Hertwig 2010; Sear and Mace 2008; Daly and Perry 2017). For infants and young children this is likely to be due to the loss of important maternal care, but this does not account for similar patterns observed among older children, who require less direct care. Another popular explanation for the relative lack of disadvantage observed in paternal orphans is that they are more likely to be cared for by maternal kin, who are predicted to invest more in children than paternal kin because they have higher certainty over genetic relatedness (Euler and Weitzel 1996). For example, a study in Canada found that maternal kin provided more stable foster care placements than paternal kin (Perry, Daly, and Macfarlan 2014). However, paternity certainty is generally very high in most contexts, so additional explanations may be needed to help explain differences in the outcomes for maternal and paternal orphans (Larmuseau, Matthijs, and Wenseleers 2016). For example, paternal orphans may continue to receive intensive investment from mothers, whereas fathers may benefit more from switching investment away from maternal orphans and towards a new relationship and new children. In this population, paternal orphans are more likely to live with their mothers than maternal orphans are to live with their fathers (50.3\% compared to $41.7 \%$ ). Additionally, among orphans, paternal orphans are less likely to live with a stepparent compared to maternal orphans ( $13.1 \%$ compared to $30.6 \%)$, suggesting that fathers may 
be more likely to switch investment away from their previous children, and that paternal orphans may be more exposed to negative step parental discrimination (Daly and Wilson 1988).

Overall though, it is perhaps most interesting that orphans do not appear particularly disadvantaged. The portrayal of orphans in the media, policy, and research is often focused on their vulnerability and lack of resources (Abebe 2012). In the wake of the HIV/AIDS epidemic and increased adult mortality, the incidence of 'crisis fostering' of orphans appears to have increased in frequency in some regions, with some commentators concerned that this puts pressure on traditional fostering networks, reducing households' ability to foster nonorphans (Grant and Yeatman 2012). During the 1990s, orphan prevalence increased significantly in Tanzania in response to the HIV epidemic (Bicego, Rutstein, and Johnson 2003). However, in many contexts such as this one, with a strong tradition of fostering and care by close kin, orphans appear to be buffered from parental loss by high levels of investment from close kin, particularly by grandparents.

\subsection{Limitations}

In common with many studies of fostering, we lack data on the households in which children would otherwise be living, and on the reasons for children living away from their parents, and so cannot say whether fostering actively benefits children in our sample or not. Using longitudinal data would enable the investigation of how children's outcomes change as they move from one household to another, as well as how factors such as length of foster placement influence outcomes. Additionally, some children may retain closer links to their parents, and may continue to receive investment, for example school fees, while others may move more permanently and rely more heavily on their foster household for investment; collecting data on monetary assistance from people outside the household might highlight circumstances in which parents continue to invest in nonresident children. In this study we control for household factors but cannot explicitly compare foster children with biological children within the same household, due to the manner in which household member relationships were recorded. However, this would be an interesting avenue for future work.

\subsection{Conclusions}

Fostering has been a puzzle in the anthropological literature, as it is a widespread phenomenon yet, due to relatively low relatedness between foster parent and child, is 
predicted to reduce children's well-being, and be costly to foster parents. Our findings suggest that children's work contributions may help explain this puzzle, allowing foster children to offset some of their costs and hence receive similar levels of investment to children living with their biological parents. While this appears to hold when there is a close genetic link between foster child and foster parents, distant kin appear less willing to invest as much in foster children's education. Our results also indicate that fostering networks are important in buffering orphans well from parental loss, even in a context such as this one where orphanhood has increased in the wake of the HIV epidemic. The focus in international policy and the media is often on fostered and orphaned children's vulnerability (Abebe 2012; Akresh 2004). However, in contexts such as this, with a strong tradition of fostering, kin reciprocity and altruism, and children's own productive contributions to their households, fostering may in fact be a beneficial part of socialisation, family relationships, and household livelihoods.

\section{Acknowledgements}

We would like to thank all the families, children, and young people who participated in our research. Our thanks also go to the National Institute of Medical Research and the Tazama Project for hosting this project, and to our enumerators Holo Dick, Pascazia Simon, and Vicky Sawalla. We are also grateful to the ESRC, the Wenner-Gren Anthropological Foundation, and the International Society for Human Ethology for funding this fieldwork project. This work was supported by the UK Economic and Social Research Council through the Bloomsbury Doctoral Training Centre, grant reference number 1360209. We are grateful for helpful comments and feedback from Abbey Viguier and Susie Schaffnit. Finally, we thank three anonymous reviewers for insightful commentary on earlier versions of this manuscript. 


\section{References}

Abebe, T. (2012). AIDS-affected children, family collectives and the social dynamics of care in Ethiopia. Geoforum 43(3): 540-550. doi:10.1016/j.geoforum.2011. 10.010 .

Ainsworth, M., Beegle, K., and Koda, G. (2002). The impact of adult mortality on primary school enrollment in Northwestern Tanzania. Washington, D.C.: The World Bank (Africa Region Human Development Working Paper Series 23961). http://documents.worldbank.org/curated/en/989271468778486753/pdf/multi0pa ge.pdf.

Akresh, R. (2004). Adjusting household structure: School enrollment impacts of child fostering in Burkina Faso. Bonn: Institute for the Study of Labor (IZA Discussion Paper 1379). http://ftp.iza.org/dp1379.pdf.

Assaad, R., Levison, D., and Zibani, N. (2010). The effect of domestic work on girls' schooling: Evidence from Egypt. Feminist Economics 16(1): 79-128. doi:10.1080/13545700903382729.

Bhalotra, S. and Heady, C. (2001). Child farm labour: The wealth paradox. Washington, D.C.: The World Bank (SP Discussion Paper 125). http://documents.worldbank.org/curated/en/247341468774880478/pdf/multi0pa ge.pdf.

Bicego, G., Rutstein, S., and Johnson, K. (2003). Dimensions of the emerging orphan crisis in sub-Saharan Africa. Social Science and Medicine 56(6): 1235-1247. doi:10.1016/S0277-9536(02)00125-9.

Bledsoe, C. (1990). 'No success without struggle': Social mobility and hardship for foster children in Sierra Leone. Man 25(1): 70-88. doi:10.2307/2804110.

Boerma, J.T., Urassa, M., Nnko, S., Ng'weshemi, J., Isingo, R., Zaba, B., and Mwaluko, G. (2002). Sociodemographic context of the AIDS epidemic in a rural area in Tanzania with a focus on people's mobility and marriage. Sexually Transmitted Infections 78(S1): i97-i105. doi:10.1136/sti.78.suppl_1.i97.

Buis, M.L. (2017). FMLOGIT: Stata module fitting a fractional multinomial logit model by quasi maximum likelihood [electronic resource]. Boston: Boston College Department of Economics. https://ideas.repec.org/c/boc/bocode/s456 976.html. 
Burke, K. and Beegle, K. (2004). Why children aren't attending school: The case of Northwestern Tanzania. Journal of African Economies 13(2): 333-355. doi:10.1093/jae/ejh011.

Chuong, C. and Operario, D. (2012). Challenging household dynamics: Impact of orphanhood, parental absence, and children's living arrangements on education in South Africa. Global Public Health 7(1): 42-57. doi:10.1080/17441692. 2011.574147.

Clarke, P. (2008). When can group-level clustering be ignored? Multi-level versus single-level models with sparse data. Journal of Epidemiology and Community Health 62: 752-758. doi:10.1136/jech.2007.060798.

Coall, D.A. and Hertwig, R. (2010). Grandparental investment: Past, present, and future. Behavioral and Brain Sciences 33(1): 40-59. doi:10.1017/S01405 $25 \times 10000014$.

Coates, J., Swindale, A., and Bilinsky, P. (2007). Household Food Insecurity Access Scale (HFIAS) for measurement of household food access: Indicator guide: Version 3. Washington, D.C.: FANTA. https://www.fantaproject.org/sites/ default/files/resources/HFIAS_ENG_v3_Aug07.pdf.

Daly, M. and Perry, G. (2017). Matrilateral bias in human grandmothering. Frontiers in Sociology 2(11): 1-8. doi:10.3389/fsoc.2017.00011.

Daly, M. and Wilson, M. (1988). Evolutionary social psychology and family homicide. Science 242(4878): 519-524. doi:10.1126/science.3175672.

Eloundou-Enyegue, P.M. and Stokes, C.S. (2002). Will economic crises in Africa weaken rural-urban ties? Insights from child fosterage trends in Cameroon. Rural Sociology 67(2): 278-298. doi:10.1111/j.1549-0831.2002.tb00104.x.

Euler, H.A. and Weitzel, B. (1996). Discriminative grandparental solicitude as reproductive strategy. Human Nature 7(1): 39-59.

Fafchamps, M. and Wahba, J. (2006). Child labor, urban proximity, and household composition. Journal of Development Economics 79(2): 374-397. doi:10.1016/ j.jdeveco.2006.01.005.

Fleisch, B., Shindler, J., and Perry, H. (2012). Who is out of school? Evidence from the Statistics South Africa Community Survey. International Journal of Educational Development 32(4): 529-536. doi:10.1016/j.ijedudev.2010.05.002. 
Franklin, P. and Volk, A.A. (2016). Evolutionary paradox: Adoption. In: Shackelford, T.K. and Weekes-Shackelford, V.A. (eds.). Encyclopedia of evolutionary psychological science. Cham: Springer International. doi:10.1007/978-3-31916999-6_2274-1.

Gaydosh, L. (2015). Childhood risk of parental absence in Tanzania. Demography 52(4): 1121-1146. doi:10.1007/s13524-015-0411-4.

Goody, E.N. (1982). Parenthood and social reproduction: Fostering and occupational roles in West Africa. Cambridge: Cambridge University Press.

Grant, M.J. and Yeatman, S. (2012). The relationship between orphanhood and child fostering in sub-Saharan Africa, 1990s-2000s. Population Studies 66(3): 279295. doi:10.1080/00324728.2012.681682.

Hadley, C. (2005). Ethnic expansions and between-group differences in children's health: A case study from the Rukwa Valley, Tanzania. American Journal of Physical Anthropology 128(3): 682-692. doi:10.1002/ajpa.20056.

Hamilton, W.D. (1964). The genetical evolution of social behaviour (I and II). Journal of Theoretical Biology 7(1): 1-52. doi:10.1016/0022-5193(64)90038-4, doi:10.1016/0022-5193(64)90039-6.

Hampshire, K.R., Porter, G., Agblorti, S., Munthali, A., and Abane, A. (2015). Context matters: Fostering, orphanhood and schooling in sub-Saharan Africa. Journal of Biosocial Science 47(2): 141-164. doi:10.1017/S0021932014000169.

Hedges, S., Sear, R., Todd, J., Urassa, M., and Lawson, D.W. (2018). Trade-offs in children's time allocation: Mixed support for embodied capital models of the demographic transition in Tanzania. Current Anthropology 59(5): 644-654. doi:10.1086/699880.

Kanjala, C., Michael, D., Todd, J., Slaymaker, E., Calvert, C., Isingo, R., Wringe, A., Zaba, B., and Urassa, M. (2012). The impact of antiretroviral therapy on adult mortality in rural Tanzania. Tropical Medicine and International Health 17(8): e58-e65. doi:10.1111/j.1365-3156.2011.02924.x.

Kishamawe, C., Isingo, R., Mtenga, B., Zaba, B., Todd, J., Clark, B., Changalucha, J., and Urassa, M. (2015). Health and demographic surveillance system profile: The Magu Health and Demographic Surveillance System (Magu HDSS). International Journal of Epidemiology 44(6): 1851-1861. doi:10.1093/ije/ dyv188. 
Larmuseau, M.H.D., Matthijs, K., and Wenseleers, T. (2016). Cuckolded fathers rare in human populations. Trends in Ecology and Evolution 31(5): 327-329. doi:10.1016/j.tree.2016.03.004.

Lawson, D.W., James, S., Ngadaya, E., Ngowi, B., Mfinanga, S.G.M., and Borgerhoff Mulder, M. (2015). No evidence that polygynous marriage is a harmful cultural practice in Northern Tanzania. PNAS 112(45): 13827-13832. doi:10.1073/ pnas. 1507151112 .

Lawson, D.W., Schaffnit, S.B., Hassan, A., Ngadaya, E., Ngowi, B., Mfinanga, S.G.M., James, S., and Borgerhoff Mulder, M. (2017). Father absence but not fosterage predicts food insecurity, relative poverty, and poor child health in Northern Tanzania. American Journal of Human Biology 29(3): e22938. doi:10.1002/ ajhb.22938.

Lopus, S. (2017). Relatives in residence: Relatedness of household members drives schooling differentials in Mozambique. Journal of Marriage and Family 79(4): 897-914. doi:10.1111/jomf.12393.

Madhavan, S., Myroniuk, T.W., Kuhn, R., and Collinson, M.A. (2017). Household structure vs. composition: Understanding gendered effects on educational progress in rural South Africa. Demographic Research 37(59): 1891-1916. doi:10.4054/DemRes.2017.37.59.

Monasch, R. and Boerma, J.T. (2004). Orphanhood and childcare patterns in subSaharan Africa: An analysis of national surveys from 40 countries. AIDS 18(S2): 55-65. doi:10.1097/00002030-200406002-00007.

Moyi, P. (2010). Household characteristics and delayed school enrollment in Malawi. International Journal of Educational Development 30(3): 236-242. doi:10.1016/ j.ijedudev.2009.11.008.

Novella, R. (2018). Orphanhood, household relationships, school attendance and child labor in Zimbabwe. Journal of International Development 30(5): 725-744. doi:10.1002/jid.3353.

Oleke, C., Blystad, A., Fylkesnes, K., and Tumwine, J.K. (2007). Constraints to educational opportunities of orphans: A community-based study from Northern Uganda. AIDS Care 19(3): 361-368. doi:10.1080/09540120600677987.

Parker, E.M. and Short, S.E. (2009). Grandmother coresidence, maternal orphans, and school enrollment in sub-Saharan Africa. Journal of Family Issues 30(6): 813836. doi:10.1177/0192513X09331921. 
Perry, G., Daly, M., and Macfarlan, S. (2014). Maternal foster families provide more stable placements than paternal families. Children and Youth Services Review 46: 155-159. doi:10.1016/j.childyouth.2014.08.016.

Prall, S.P. and Scelza, B.A. (2017). Children fosterage and sex-biased nutritional outcomes among Namibian pastoralists. American Journal of Human Biology 29(6): e23058. doi:10.1002/ajhb.23058.

Reghupathy, N., Judge, D.S., Sanders, K.A., Canisio Amaral, P., and Schmitt, L.H. (2012). Child size and household characteristics in rural Timor-Leste. American Journal of Human Biology 24(1): 35-41. doi:10.1002/ajhb.21232.

Roby, J.L., Erickson, L., and Nagaishi, C. (2016). Education for children in subSaharan Africa: Predictors impacting school attendance. Children and Youth Services Review 64: 110-116. doi:10.1016/j.childyouth.2016.03.002.

Scelza, B.A. and Silk, J.B. (2014). Fosterage as a system of dispersed cooperative breeding: Evidence from the Himba. Human Nature 25(4): 448-464. doi:10.1007/s12110-014-9211-6.

Schaffnit, S.B., Hassan, A., Urassa, M., and Lawson D.W. (2019). Parent-offspring conflict unlikely to explain 'child marriage' in northwestern Tanzania. Nature Human Behaviour 3: 346-353. doi:10.1038/s41562-019-0535-4.

Schaffnit, S.B., Urassa, M., and Lawson, D.W. (2019). 'Child marriage' in context: Exploring local attitudes towards early marriage in rural Tanzaniza. Sexual and Reproductive Health Matters 27(1): 1571304. doi:10.1080/09688080.2019. 1571304.

Sear, R. and Mace, R. (2008). Who keeps children alive? A review of the effects of kin on child survival. Evolution and Human Behavior 29(1): 1-18. doi:10.1016/ j.evolhumbehav.2007.10.001.

Serra, R. (2009). Child fostering in Africa: When labor and schooling motives may coexist. Journal of Development Economics 88(1): 157-170. doi:10.1016/j. jdeveco.2008.01.002.

Shapiro, D. and Tambashe, B.O. (2001). Gender, poverty, family structure, and investments in children's education in Kinshasa, Congo. Economics of Education Review 20(4): 359-375. doi:10.1016/S0272-7757(00)00059-5.

Silk, J.B. (1980). Adoption and kinship in Oceania. American Anthropologist 82(4): 799-820. doi:10.1525/aa.1980.82.4.02a00050. 
Urassa, M., Boerma, J.T., Ng'weshemi, J.Z.L., Isingo, R., Schapink, D., and Kumogola, Y. (1997). Orphanhood, child fostering and the AIDS epidemic in rural Tanzania. Health Transition Review 7(S2): 141-153.

Varkevisser, C.M. (1973). Socialization in a changing society: Sukuma childhood in rural and urban Mwanza, Tanzania. The Hague: Centre for the Study of Education in Changing Societies.

Wijsen, F. and Tanner, R. (2002). 'I am just a Sukuma': Globalization and identity construction in Northwest Tanzania. Amsterdam: Rodopi. doi:10.1163/9789 004334311 .

Zimmerman, F.J. (2003). Cinderella goes to school: The effects of child fostering on school enrollment in South Africa. The Journal of Human Resources 38(3): 557-590. doi:10.2307/1558768. 
Hedges et al.: Earning their keep? Fostering, children's education, and work in north-western Tanzania 